\title{
MEMBANGUN MORALITAS ANAK BANGSA MELALUI PENDIDIKAN TASAWUF
}

\author{
Moh. Saifulloh \\ UPT PMK Sosial Humaniora, FBMT, Institut Teknologi Sepuluh Nopember \\ Email: saiful@mku.its.ac.id
}

\begin{abstract}
ABSTRAK
Bangsa Indonesia adalah bangsa yang sejak dahulu dikenal sebagai bangsa yang sangat menjunjung tinggi adat ketimuran dengan moralitasnya yang santun, ramah dan beradab. Namun pada saat ini realitas bangsa Indonesia telah mengalami degradasi moral yang sangat memprihatinkan. Hal ini tampak jelas pada banyaknya kasus yang telah terjadi, seperti tawuran antar pelajar, pencurian, perampokan, pemerkosaan, seks bebas, miras, narkoba dan yang sedang trend saat ini menjamurnya korupsi hampir di semua institusi negara. Berbagai upaya cerdas sudah banyak dilakukan oleh kaum cerdik pandai baik melalui pendidikan formal maupun non formal untuk mencarikan solusinya, seperti seminar membangun karakter, training spiritual, manajemen qolbu dan lainnya, ternyata semuanya belum mampu merubah anak bangsa menjadi bermoral dan berkarakter, bahkan gerakan revolusi mental yang dicanangkan Presiden RI juga belum membuahkan hasil, bahkan kemerosotan moral semakin menggurita melanda bangsa Indonesia. Solusi cerdas yang ditawarkan penulis untuk membangun kembali moralitas anak bangsa adalah melalui pendidikan tasawwuf, yaitu pendidikan yang menekankan aspek pendalaman spiritual. Dalam analisis Penulis, pendidikan yang diterapkan di Indonesia selama ini masih menitik beratkan pada aspek lahiriyah (eksoteris) belum menyentuh aspek batiniyah (esoteris), dalam arti pendidikan yang hanya mengedepankan rasionalitas dan meninggalkan aspek spiritualitas. Oleh karena itu jika pendidikan di Indonesia ke depan mulai dari tingkat SD sampai PT memprioritaskan aspek esoteris, yaitu pendidikan modern yang berakar pada nilai-nilai spirit tasawuf, seperti tumbuhnya sikap jujur, sabar, tawakkal, qana'ah, amanah, disiplin, tanggung jawab dan lainnya, maka moralitas anak bangsa yang bermartabat akan terwujud dan menjadi kenyataan

Kata kunci : membangun, moralitas, anak bangsa, tasawuf
\end{abstract}

\section{PENDAHULUAN}

Islam adalah agama kasih sayang (rahmatal lil 'alamin) yang kehadirannya sangat diharapkan dapat membangun moralitas anak bangsa. Kehadiran Islam dengan seperangkat nilai-nilai moral (akhlak) sebenarnya sudah lama mengkristal dan menjadi budaya bangsa, karenanya tidak salah jika bangsa Indonesia sejak dahulu dikenal sebagai bangsa yang ramah, santun dan sangat menjunjung tinggi adat ketimuran dengan moralitasnya yang sangat beradab. Kita boleh bangga dengan sebutan tersebut, namun realitanya saat ini bangsa Indonesia telah mengalami dekadensi moral atau krisis moral yang meresahkan, bahkan sudah sangat memprihatinkan. Hal ini nampak jelas pada banyaknya kasus-kasus yang telah terjadi, seperti tawuran antar pelajar, pencurian, perampokan, pemerkosaan, seks bebas, miras, narkoba dan yang sedang trend saat ini menjamurnya korupsi hampir di semua institusi negara.

Disamping krisis moral tersebut, bangsa Indonesia juga menghadapi krisis globalisasi, sebagaimana dikemukakan oleh Sayyid Hussein Nasr, bahwa pada abad ke-21 ini dunia Islam termasuk Indonesia sedang menghadapi sejumlah tantangan serius yaitu: (1) globalisasi (2) krisis lingkungan (3) post modernisme (4) sekulerisasi kehidupan (5) krisis ilmu pengetahuan dan teknologi (6) penetrasi nilai-nilai non Islam (7) pengaburan citra Islam (8) sikap terhadap peradaban lain (9) feminisme (10) hak asasi manusia dan (11) tantangan internal. Jika berbagai krisis moral yang 
melanda negeri ini tidak segera dicarikan solusinya, maka bangsa Indonesia dalam bahaya besar yang bukan hanya mengalami keterpurukan dan kemunduran, tetapi berada diambang kehancuran. (Nasr, 1997).

Mensikapi berbagai krisis tersebut, Sayyed Hussein Naser mencoba memberikan jalan ke luar dari krisis tersebut. Seruan pertama ditujukan kepada masyarakat barat modern, beliau menyarankan agar manusia modern kembali kepada hikmah spiritual agama dan membatasi diri dalam mengejar kesenangan duniawi. Seruan kedua ditujukan kepada masyarakat Islam, agar menggagas pembaruan pemikiran Islam dengan mengkaji kembali konsep-konsep warisan pemikiran Islam klasik dan tidak mengambil konsep-konsep modernisasi barat. (Saifulloh, 2008).

Sebenarnya sudah banyak upaya dilakukan oleh kaum cerdik pandai untuk mencarikan solusi dari berbagai problem tersebut, seperti kemendikbud dengan intruksi kurikulum berbasis karakternya, namun belum bisa menjadikan peserta didik menjadi santun dan berkarakter. Ulama, kyai dan ustadz di pondok pesantren dengan berbagai kurikulum kitab kuningnya belum mampu mencetak santri berakhlaq. Para Muballigh dengan berbagai manajemen qolbunya belum mampu menggugah nurani anak bangsa menjadi bermoral. Training spiritual yang banyak digelar dan diseminarkan di kampus-kampus belum mampu merubah cara berfikir dan berperilaku santun mahasiswa, dan berbagai gerakan moral termasuk gerakan revolusi mental yang didengungkan Presiden RI juga belum membuahkan hasil, bahkan nampaknya kemerosotan moral semakin menggurita melanda bangsa Indonesia.

Dalam pengamatan penulis pendidikan untuk anak bangsa yang diterapkan di Indonesia selama ini masih menitik beratkan pada aspek lahiriyah (eksoteris) dan telah meninggalkan aspek batiniyah (esoteris), hanya mengedepankan rasionalitas dan meninggalkan aspek spiritualitas. Hal inilah yang menjadi pemicu utama dekadensi moral di negeri ini. Solusi cerdas yang ditawarkan Penulis untuk membangun moralitas anak bangsa adalah dengan revolusi spiritual melalui pendidikan tasawuf, yaitu pendidikan yang memprioritaskan aspek spiritualitas disamping aspek rasionalitas.

\section{TASAWUF DAN HUBUNGANNYA DENGAN MORAL}

Perlu difahami bahwa istilah tasawuf memang tidak pernah dikenal pada masa Rasulullah, khulafa' ar-rasyidin, maupun masa tabi'in. Istilah tasawuf baru muncul dan dikenal pada pertengahan abad III hijriyah, yang dicetuskan oleh Abu Hasyim al-Kufi (wafat $250 \mathrm{H}$ ) dengan meletakkan kata al-sufi dibelakang namanya. Tapi secara substansial kehidupan Rasulullah dan para sahabatnya sudah mencerminkan kehidupan sufi yang indentik dengan, zuhud, wara, qana'ah, tawakkal, faqir dan lainnya.

Untuk lebih mengenal tasawuf, akan kami paparkan pengertian tasawuf baik secara etimologi maupun terminologinya. Secara etimologi kata tasawuf diambil dari beberapa kata diantaranya: Pertama, tasawuf berasal dari kata "suf" yang berarti "wol", yaitu untuk menunjukkan penggunaan jubah wol. Kata suf (kain wol) menggambarkan orang yang hidup sederhana dan tidak mementingkan dunia. Dari segi linguistic (kebahasaan) dapat dipahami bahwa tasawuf adalah sikap mental yang selalu memelihara kesucian diri, beribadah, hidup sederhana, rela berkorban untuk kebaikan dan selalu bersikap kebajikan. Sikap jiwa yang demikian itu pada hakikatnya adalah akhlak mulia.

Kedua, dari kata "sufi" yang artinya suci. Seorang sufi adalah orang yang disucikan dan kaum sufi adalah orang-orang yang telah mensucikan dirinya melalui latihan spiritual. Dengan kata lain, sufi merupakan orang yang mensucikan dirinya dengan banyak mengingat Allah (dzikrullah), menempuh jalan kembali kepada Allah sampai kepada pengetahuan yang hakiki tentang Allah (ma rifatullah). (Nilyati, 2015). Dari kedua pengertian di atas dapatlah difahami bahwa orang yang menempuh hidup tasawuf berarti orang yang berusaha untuk mensucikan dirinya di hadapan Allah Swt, sehingga akan muncul seseorang yang bermoral atau berperilaku baik (akhlaq al-karimah). 
Sedangkan pengertian secara terminologi dirumuskan oleh para sufi di antaranya yang terpenting adalah: Pertama, menurut Sahal al-Tustury (wafat $283 \mathrm{H}$ ), tasawuf adalah seseorang yang hatinya bersih dari kotoran dosa, berhubungan baik dengan sesama manusia dan memandang sama antara emas dengan kerikil. Kedua, menurut Abu Muhammad al-Jariri (wafat $311 \mathrm{H}$ ). Ketika ditanya tentang tasawuf beliau menjawab, tasawuf adalah memasuki akhlak yang mulia (bermoral) dan keluar dari setiap akhlak yang tercela. Ketiga, menurut Abu Husain an-Nuri (wafat $295 \mathrm{H}$ ) tasawuf bukanlah suatu bentuk ilmu, tetapi ia adalah akhlak mulia, sekiranya ia hanya sekedar bentuk tulisan maka bisa diusahakan dengan sungguh-sungguh, seandainya ia ilmu tentu akan bisa diperoleh dengan belajar. Namun tasawuf adalah berakhlak dengan akhlak Allah, sedangkan akhlak llahi tidak dapat dicapai dengan tulisan maupun ilmu. (Mahmud, 2001).

Dari berbagai definisi tersebut di atas, dapatlah difahami bahwa tasawuf adalah ajaran Islam yang mengajarkan bagaimana seharusnya sikap mental (moral) seorang muslim dalam berhubungan baik dengan Tuhannya (vertikal) dan berhubungan baik dengan sesama manusia (horisontal) dan dengan makhluk lainnya yang didasarkan atas petunjuk al-Qur'an dan al-Hadits. Dari pengertian ini diharapkan terbentuk manusia sempurna (insan kamil), yaitu manusia yang memiliki akhlak mulia dan terpuji dan itulah sejatinya misi utama diutusnya Rasulullah Muhammad Saw, yaitu untuk menyempurnakan akhlak manusia, sebagaimana sabdanya, yang artinya: "Tidaklah Aku diutus kecuali hanya untuk menyempurnakan akhlak yang luhur".

Dari penjelasan di atas dapatlah dimengerti bahwa tasawuf sebenarnya identik dengan moral Islam itu sendiri, dengan pemahaman bahwa tasawuf merupakan proses pendekatan diri kepada Allah dengan cara mensucikan hati (tashfiyat al-qalbi), jika hatinya bersih dan suci maka yang akan keluar adalah perbuatan perilaku moral yang baik dan mulia (al-akhlaq al-karimah), hati yang suci bukan hanya bisa dekat dengan Allah tapi malah dapat mengenal Allah (al-ma'rifatullah).

Jadi hubungan tasawuf dengan moral ( $\mathrm{k} h \mathrm{hlaq}$ ), adalah tasawuf merupakan cara atau metode untuk membersihkan dan mensucikan hati, dan dari hati yang telah suci bersih membuahkan moral yang beradab (akhlaq al-karimah). Maka hubungan antara tasawuf dengan moral menjadi sangat erat, karena satu sama lain saling mendukung, dan saling mempengaruhi. Dengan kata lain, tasawuf berbanding lurus dengan moral, sehingga sangat tepat jika pendidikan tasawuf dijadikan amunisi yang manjur untuk membangun moralitas anak bangsa, dan para sufi dan para pendidik harus berada di garda depan untuk mewujudkannya.

\section{AJARAN TASAWUF DALAM SOROTAN}

Tasawuf memang sering mendapatkan sorotan, kritikan dan tuduhan menyakitkan. Beberapa orientalis barat dan pemikir Muslim sendiri tidak sedikit yang menuduh tasawuf menjadi biang kemunduran peradaban Islam. Tasawuf dituduh sebagai "virus" yang menghambat kemajuan dan menyebabkan ketertinggalan dunia muslim dalam kancah peradaban modern. Ajaran dan doktrin tasawuf seperti, zuhud, qanaah, tawakkal, wirid, dzikir dan lainnya, membuat seseorang menjadi malas, bodoh, miskin dan terbelakang. Bahkan yang lebih menyakitkan, tuduhan kelompok-kelompok Islam puritan (salafi-wahabi) menganggap tasawuf sebagai bid'ah dan khurafat yang menyesatkan, karena tidak ada tuntunanya dari Rasulullah dan para Sahabatnya.(Siroj, 2006)

Pemahaman di atas sangat tidak benar, karena ajaran tasawuf seperti zuhud, qonaah, tawakkal, wirid, dzikir dan lainya merupakan ajaran Islam yang bersumber dari al Qur'an dan al Hadits. Jika ada seseorang yang mempunyai pemahaman yang negatif tentang ajaran tasawuf, maka itu bukanlah ajaran tasawuf yang salah, tetapi sangat dimungkinkan persepsi orang terhadap ajaran tasawuf itulah yang keliru. Ajaran zuhud misalnya, tidaklah diartikan dengan meninggalkan kehidupan dunia atau membenci dunia, akan tetapi yang tepat adalah hidup sederhana, hidup bersahaja artinya tidak boros dan tidak hidup berfoyafoya (hedonis). Dengan demikian, zuhud bukan berarti tidak perlu kerja keras mencari uang, tetapi yang benar setelah uang diperoleh dari kerja keras tersebut tidak boleh dihambur-hamburkan yang pada akhirnya melupakan Allah Swt, seperti 
tidak mengeluarkan zakat atau meninggalkan shalat dengan alasan sibuk kerja. (Saifulloh, 2012). Selanjutnya tawakkal adalah upaya berserah diri dan ridla dalam menerima keputusan Allah. Apabila kehendak Allah sesuai dengan yang kita inginkan, maka diharuskan untuk mensyukurinya. Namun apabila ternyata keputusan Allah tidak sesuai dengan yang diharapkan, maka ia harus bersabar dan tabah mengahadapinya. Ajaran tawakkal dalam perspektif tasawuf harus difahami bahwa jika sukses tidak sombong dan jika gagal tidak akan fustrasi dan patah semangat. Sikap syukur apabila sukses dan sabar apabila gagal merupakan mutiara yang sangat berharga yang harus dimiliki oleh seorang muslim, dan hal ini perlu diwariskan pada anak bangsa agar memiliki moral yang tangguh dalam kehidupannya.

Sedangkan qana'ah berarti merasa cukup dan merasa puas dengan pemberian Allah. Jadi qana'ah bukan berarti pasrah menerima takdir atau ketentuan Allah dengan berpangku tangan tidak perlu bekerja keras. Orang harus bekerja keras atau beretos kerja tinggi, tetapi berapapun hasilnya diusahakan hati merasa puas agar tidak menjadi serakah dan rakus. Jadi qana'ah mengajarkan pada kita agar seseorang tidak mencari uang dengan jalan haram hanya karena pekerjaan halalnya tidak mencukupi atau tidak menghasilkan uang sebanyak yang diperlukan. (Teba, 2009).

Sedangkan ajaran tasawuf seperti wirid dan dzikir dianggap banyak menyita waktu dan menyebabkan orang menjadi malas belajar dan bekerja adalah asumsi yang tidak benar, karena ritual dzikir tidak harus dilakukan pada jam kerja. Orang orang tasawuf atau yang dikenal dengan sufi banyak mengamalkan wirid dan dzikir banyak dilakukan malam hari atau hari libur, sehingga tidak mengganggu pekerjaan. Dan yang perlu diketahui bahwa para pengamal tasawuf itu mempunyai amalan dzikir rahasia (dzikir sirrî) yang dapat diamalkan setiap waktu, malaupun saat belajar atau bekerja sekalipun. Jadi belajar, bekerja dan berdzikir dapat dilakukan berlama-lama, tanpa harus berhenti belajar dan bekerja. Inilah kelebihan ajaran tasawuf yang mungkin berbeda dengan ajaran lainya dalam membangun moralitas anak bangsa ke arah yang lebih baik.(Saifulloh, 2012).

Berdasarkan paparan di atas dapatlah Penulis jelaskan bahwa semua tuduhan di atas salah, tidak benar dan sangat tidak beralasan, jikalau umat Islam ini ada yang malas belajar dan bekerja, bodoh, miskin, tebelakang dan klaim lainnya, itu bukanlah disebabkan oleh ajaran tasawuf, tapi sangat dimungkinkan adanya faktor lain sebagai pengebabnya. Jika kita melihat sejarah masa lalu, banyak para sufi yang justru memajukan peradaban Islam. Para sufi dikenal dengan keilmuannya yang ensiklopedis. Kita bisa sebutkan seperti Syekh Sahl At-Tasturi, seorang sufi yang ahli tafsir. Syekh Ibnu Arabi, seorang sufi yang mengedepankan tasawuf-falsafi dikenal pula sebagai ahli tafsir dan hadits. Syekh Ibnul Farid dan Syekh Fariduddin Al-Aththar adalah dua figur sufi yang dikenal luas sebagai sastrawan. (Siroj, 2006).

Jadi di jaman modern dan era global yang serba materialistik yang gersang dari nilai-nilai spiritualitas ini, kehadiran tasawuf dalam dunia pendidikan justru sangat dibutuhkan. Menurut Penulis kejumudan dan kemunduran umat Islam bukan disebabkan doktrin dan ajaran tasawuf, melainkan justru akibat umat Islam meninggalkan nilai-nilai tasawuf dan terjebak dalam kubangan fitnah duniawi yang materialistis, sehingga pudarlah nilai kemanusiaan, persatuan, dan solidaritas, yang pada akhirnya bangsa ini mudah dimasuki oleh pengaruh asing, seperti kapitalisme, liberalisme, radikalisme, dan terorisme.(Nata, 2012)

Tasawuf seperti dikatakan Reynold A. Nicholson merupakan salah satu unsur yang vital dalam Islam, sehingga tanpa adanya pemahaman mengenai gagasan dan bentuk-bentuk sufistik yang mereka kembangkan, kita bersusah payah menelusuri kehidupan keagamaan Muhammad yang tampak di permukaan saja. Shahib Khaja Khan mengatakan juga, kalau Islam dipisahkan dari aspek esoteriknya (tasawuf), maka ia hanya akan menjadi kerangka formalitas yang gersang dari sentuhan ilahiyah, yang akhirnya melahirkan manusia-manusia yang tidak bermoral.

Menurut Komarudin Hidayat yang dikutip oleh Abudin Nata, sufisme perlu untuk dimasyarakatkan dengan tujuan : Pertama, turut serta terlibat dalam berbagai peran dalam menyelamatkan kemanusiaan dari kondisi kebingungan akibat hilangnya nilai-nilai spritual. Kedua, memperkenalkan literatur atau pemahaman tentang aspek esoteris (kebatinan Islam), baik terhadap 
masyarakat Islam yang mulai melupakannya maupun non Islam, khususnya terhadap masyarakat Barat. Ketiga, untuk memberikan penegasan kembali bahwa sesungguhnya aspek esoteris Islam, yakni sufisme, adalah jantung ajaran Islam, sehingga apabila wilayah ini kering dan tidak berdenyut, maka keringlah aspek-aspek yang lain ajaran Islam. (Wanto, 2014)

\section{MEMBANGUN MORALITAS ANAK BANGSA DENGAN PENDIDIKAN TASAWUF}

Telah di jelaskan sebelumnya bahwa tasawuf sebenarnya adalah moral Islam itu sendiri. Makanya Solusi cerdas yang ditawarkan Penulis untuk membangun moralitas anak bangsa adalah dengan to return to god through religion (kembali kepada Tuhan melalui agama), yaitu revolusi spiritual melalui pendidikan tasawuf, yaitu pendidikan yang fokus membersihkan jiwa dari segala noda dosa dengan dibawah bimbingan seorang guru spiritual yang disebut Mursyid.

Nilai substansial dari pendidikan tasawuf itu adalah proses penyucian jiwa (tazkiyat an-nafs) untuk mencapai kedekatan kepada Allah dengan sedekat-dekatnya. Penyucian ini penting dalam rangka mendekatkan diri kepada Yang Mahasuci, yaitu Allah SWT, karena Yang Mahasuci hanya bisa didekati oleh yang suci juga. Penyucian diri yang bisa berbentuk menahan diri dari hawa nafsu, syahwat dan amarah. Membersihkan diri dari sifat-sifat tercela, atau melakukan latihan- latihan jiwa (riyadhat al-nafs) dalam berbagai disiplin, termasuk 'uzlah, zuhud, dan latihan jiwa lainnya. (Siroj, 2006).

Dengan pemahaman lain, bahwa spritualitas dalam kaitannya dengan manusia, lebih menekankan aspek rohaninya ketimbang jasmaninya, dalam kaitannya dengan kehidupan, ia lebih menekankan kehidupan akhirat daripada dunia yang fana, sedangkan dalam kaitannya dengan pemahaman keagamaan, ia lebih menekankan aspek esoterik ketimbang eksoterik, lebih menekankan penafsiran batiniyah ketimbang lahiriyah. Akan tetapi dalam pendidkan tasawuf bukan berarti mengabaikan nilai-nilai syari'at (nilai- nilai formalistik dalam Islam). Pendidikan tasawuf yang benar adalah adanya pendidikan tawazun (keseimbangan) antara keduanya yaitu unsur lahir (formalistik) dan batin (substansialistik).

Dalam pengamatan penulis pendidikan yang diterapkan di Indonesia selama ini masih menitik beratkan pada aspek lahiriyah (eksoteris) yang hanya mengedepankan rasionalitas dan meningalkan aspek batiniyah (esoteris) atau aspek spiritualitas. Hal inilah yang menjadi pemicu utama dekadensi moral di negeri ini. (Teba, 2009). Jika pendidikan di Indonesia mulai dari SD sampai tingkat PT ke depan memprioritaskan aspek esoteris, yaitu pendidikan modern yang sarat nilai-nilai spiritual, seperti tumbuhnya sikap jujur, sabar, tawakkal, qana'ah, amanah, disiplin, tanggung jawab, dan lainnya, maka ke depan bangsa yang bermoral dan bermartabat akan menjadi kenyataan.

Nurcholis Madjid mengemukakan bahwa substansi dalam pendidikan tasawuf adalah penghayatan esoteris yang bersifat spritual. Contohnya, kalau para ahli figh atau guru agama Islam mengajarkan atau membahas mengenai sholat, maka yang dibicarakan adalah bagaimana pakaiannya, tempatnya, suci apa tidak, bagaimana wudhu'nya sudah benar apa belum dan bagaimana kiblatnya dan lainnya. Kesemuanya itu dalam pandangan sufi sebagai "trivial things" (suatu hal yang lumrah sekali). Bagi para sufi, sholat itu sebagai suatu peristiwa dialog dengan Allah, serta sebagai peristiwa mengintenskan kesadaran akan kehadiran seorang makhluk di depan khaliknya dan khalik dalam kehidupan seseorang. Maka para sufi ini suka mengatakan bahwa sholat ini merupakan eskalasi atau mi'raj bagi hambanya yang beriman.(Wanto, 2014).

Menurut analisis Penulis, Srategi pendidikan tasawuf sebenarnya telah digagas oleh WR Supratman, sebagaimana dalam syair lagu Indonsia raya yang berbunyi: "Bangunlah jiwanya, bangunlah badannya, untuk Indonesia raya". Dalam syair lagu tersebut mengandung filosofi pendidikan tasawuf yang dalam, strategi dalam membangun Indonesia ke depan, terutama dalam membangun moralitas anak bangsa ini. Strategi utama adalah bangunlah jiwanya, artinya bangunan 
yang harus diprioritaskan dan utamakan adalah membangun jiwa (spiritualitas) dan strategi kedua adalah bangunlah badannya artinya membangun material (lahiriyah). Dengan analog membangun gedung, jembatan, jalan dan lainnya itu penting tapi yang lebih penting lagi adalah membangun jiwa, ruhani, moral (akhlak) manusia yang membangun gedung, jembatan tersebut. Hal ini yang sering diabaikan, pendidikan selama ini hanya transfer ilmu dan melupakan moral, sehingga di negeri ini banyak bermunculan orang pinter tetapi sulit mencari orang yang benar dan bermoral.

Ada beberapa strategi pendidikan tasawuf yang ditawarkan para sufi dalam mencerdaskan ruhani yang harus ditanamkan dalam semua jenjang pendidikan di Indonesia sebagai upaya membangun moralitas anak bangsa. Pertama, adalah dengan penyucian jiwa (tazkiyat an-nafs) yang meliputi: 1. Ijtinabul manhiyat, ialah menjauhi larangan-larangan Allah. Semua larangan Allah wajib ditinggalkan dengan segala kemampuannya, tidak boleh pilih-pilih. 2. Ada'ul wajibat, ialah melaksanakan kewajiban-kewajiban Allah. Semua perintah Allah wajib dilaksanakan, sesuai kemampuannya tapi dalam batas yang telah ditentukan 3. Ada'un nafilat, ialah melaksanakan hal-hal yang disunahkan Allah, sebagai ibadah penyempurna ibadah wajib dan 4. Ar-Riyadlah, ialah latihan spiritual agar dapat istiqamah dalam menjalankan seluruh ajaran Islam dan mendekatkan diri kepada Allah dengan banyak dzikir-Nya (dzikran katsira).(Mansoer, 2004)

Strategi kedua, adalah Mujahadah an-Nafs, adalah latihan pembersihan jiwa, sehingga membuahkan moral yang baik, dilakukan dalam tiga tingkatan, yaitu: Pertama Takhalli, yaitu suatu usaha mengosongkan diri dari sifat- sifat yang tercela dan maksiat lahir maupun batin, seperti: sikap gampang marah, mudah tersinggung, buruk sangka, senang pamer, gila pangkat, gila dunia, banyak mengumpat, banyak bicara. Selama manusia belum membenci, membuang kebiasaan jelek tesebut, maka nafsu akan senantiasa memperbudak manusia. Kedua Tahalli, yaitu suatu usaha untuk mengisi diri dengan sifat-sifat yang terpuji dan taat secara lahir dan batin, seperti: jujur, sabar, ikhlas, amanah, khusnudhan, pemaaf, pemurah, syukur, sabar, ridha, tawakkal dan lainnya. Ketiga Tajalli, yaitu suatu tingkatan di mana ia merasakan rasa ketuhanan dengan mencapai kenyataan hakikat mengenal Allah, seperti: perasaan tenang, tentram, bahagia, ceria, dinamis, istiqamah, selalu rindu cinta tertuju pada Allah, apa saja yang menimpa dirinya baik nikmat maupun musibah dirasakannya sebagai kasih sayang Allah kepada hamba-Nya.(Ausop, 2014).

Dalam perspektif sejarah Islam dunia dan Indonesia, spiritualitas telah terbukti menjadi kekuatan yang luar biasa dalam menciptakan individu yang suci, memiliki integritas dan akhlakul karimah yang keberadaannya bermanfaat kepada orang lain. Secara social, pendidikan tasawuf yang berbasis spiritualitas mampu membangun masyarakat Islam mencapai puncak peradaban, mampu mencapai predikat khairah ummat dan keberadaannya mebawa kebahagiaan serta kemaslahatan untuk semua. (rahmatan lil alamin). Karenanya jika ingin membangun moral anak bangsa, maka dalam pendidikan modern ke depan wajib memprioritaskan aspek spiritualitas yaitu pendidikan yang sarat nilai-nilai tasawuf, seperti tumbuhnya sikap jujur, amanah, disiplin, tanggung jawab, sabar dan lainnya.

Jika beberapa metode tersebut dijadikan gerakan revolusi spiritual di semua jenjang pendidikan formal maupun non formal di Indonesia juga oleh masyarakat khususnya peserta didik dan berkomitmen untuk diimplementasikan dalam kehidupan modern yang gersang akan spiritual ini, maka dalam waktu cepat berbagai krisis multidimensi yang melanda bangsa ini akan segera terobati.

\section{KESIMPULAN}

Pendidikan Tasawuf strategi utamanya adalah pendekatan diri pada Allah dengan mensucikan hati (tashfiyat al-qalbi), karena hati yang sudah bersih dan suci maka yang muncul adalah perbuatan baik dan mulia (al-akhlaq al-karimah), hati yang suci bukan hanya bisa dekat dengan Allah tapi malah dapat mengenal Allah (al-ma'rifatullah). Jadi pendidikan tasawuf identik 
dengan pendidikan moralitas itu sendiri, maka sangatlah tepat jika pendidikan tasawuf dijadikan amunisi utama dalam perbaikan moralitas anak bangsa.

Di jaman global era revolusi Industri 4.0 yang serba digital dan serba materialistik yang gersang dari nilai-nilai spiritualitas ini, kehadiran pendidikan tasawuf justru sangat dibutuhkan. Krisis multidimensi, kejumudan dan kemunduran umat bukan disebabkan doktrin dan ajaran tasawuf yang salah, melainkan justru akibat dunia pendidikan dan masyarakat Indonesia meninggalkan nilai-nilai tasawuf. Dekadensi moral yang melanda masyarakat modern saat ini, diakibatkan keringnya penghayatan terhadap nilai-nilai spritual.

Solusi cerdas yang ditawarkan Penulis untuk membangun moralitas anak bangsa adalah dengan pendidikan yang memprioritaskan dan mengedepankan nilai-nilai tasawuf, seperti: tazkiyatun nafs, mujahadah, muraqabah, muhasabah dan lainnya, dalam kehidupan masyarakat terutama lembaga pendidikan. Jika pendidikan di Indonesia ke depan memprioritaskan aspek esoteris, yaitu pendidikan modern yang sarat nilai-nilai spiritual, seperti tumbuhnya sikap jujur, sabar, tawakkal, qana'ah, amanah, disiplin, tanggung jawab, dan lainnya, maka anak bangsa yang bermoral dan bermartabat akan menjadi kenyataan.

\section{DAFTAR PUSTAKA}

Ausop, A. Z. (2014). Islamic Character Building: Membangun Insan Kamil,Cendekia Berakhlak Qurani (Cet.I). Bandung: Salamadani.

Mahmud, A. H. (2001). Tasawuf di Dunia Islam. (M. Abdul Jaliel, Ed.) (I). Bandung: Pustaka Setia.

Mansoer, H. (2004). Materi Instruksional :Pendidikan agama Islam di Perguruan Tinggi Umum. Jakarta: Direktur PTAI Depag RI.

Nasr, S. H. (1997). Sufi Essays (I). USA: State University New York Preess.

Nata, A. (2012). Akhlak Tasawuf dan Karakter Mulia (I). Jakarta: Grafindo.

Nilyati. (2015). Peranan tassawuf dalam kehidupan modern. Tajdid : Jurnal Penelitian Sosial Keagamaan, XIV(1), 119-142.

Saifulloh, M. (2008). Tasawuf sebagai Solusi Alternatif dalam Problematika Modernitas. Islamica: Jurnal Studi Keislaman, 2, 207-216.

Saifulloh, M. (2012). Etos kerja pengikut tarekat qâdirîyah wa naqshabandîyah. Teosofi: Jurnal Tasawuf Dan Pemikiran Islam, 2(2), 1-28.

Siroj, S. A. (2006). Tasawuf sebagai Kritik Sosial: Mengedepankan Islam sebagai Inspirasi bukan Aspirasi (I). Bandung: Mizan.

Teba, S. (2009). Tasawuf Positif (3rd ed.). Bandung: Mizan.

Wanto, S. (2014). Pendekatan Tasawuf dalam Studi Islam dan Aplikasinya di Era Modern. Jurnal At Tafkir: IAIN Medan, VII(1), 131-144. 